\title{
The Profile of Critical Thinking Skill Students in XI Grade of Senior High School
}

\author{
$1^{\text {st }}$ Evi Elisanti \\ Science Education, Postgraduate \\ Program \\ Sebelas Maret University (UNS) \\ Surakarta, Indonesia \\ vv.vizvalen@gmail.com
}

\author{
$2^{\text {nd }}$ Sajidan \\ Science Education, Postgraduate \\ Program \\ Sebelas Maret University (UNS) \\ Surakarta, Indonesia \\ sajidan@fkip.uns.ac.id
}

\author{
$3^{\text {rd }}$ Baskoro Adi Prayitno \\ Science Education, Postgraduate \\ Program \\ Sebelas Maret University (UNS) \\ Surakarta, Indonesia \\ baskoro_ap@fkip.uns.ac.id
}

\begin{abstract}
The development of the 21 st century requires learners to have a sophisticated knowledge insight in the era of global competition. The 21st-century generation must master high-order thinking skills. One of them is critical thinking skills. Critical thinking skills are skills that learners must possess. This study aims to analyze the profile of students' critical thinking skills with purposive sampling technique. Participants of this study were 234 students of class XI SMA Negeri (Public Senior High School) Academic Year 2016-2017. The test is in essay form that is tailored to the indicator of critical thinking skills according to Facione. Data were analyzed by a qualitative descriptive method. Based on the results of data analysis that students' critical thinking skills were still categorized as low. The percentage obtained from result of analysis about essay test that used got average mean value of interpretation aspect equal to $46,03 \%$ with low category, analysis aspect $60,20 \%$ with medium category, evaluation aspect equal to $42,82 \%$ with low category, aspect of inference is $40,16 \%$ with low category, explanation aspect $53,65 \%$ with low category, and self-regulation aspect $32,20 \%$ with low category. It was caused students got difficult for classifying, coding, categorizing, reviewing ideas, assessing arguments, analyzing arguments, assessing questions and assessing arguments, asking for evidence, alternative allegations, drawing conclusions, stating outcomes, justifying procedures, presenting arguments and self-examinations, corrections self. The results of this study provide information about the profile of students 'critical thinking skills so that teachers are expected to be able to design the process of learning activities, develop a specific subject of pedagogy with innovative learning models that can empower students' critical thinking skills.
\end{abstract}

Keywords—profile, critical thinking skills, students

\section{INTRODUCTION}

Nowadays, critical thinking skills have been the primary focus of education [1]. Education as a key instrument of one's personal qualities development can be a valuable intellectual resource for a nation [2]. The importance of developing students' critical thinking skills in education [3]. Expanding the potential to become a resource for future learning extensively [3]. The development of critical thinking skills is one of the critical elements of science literacy [4]. To train and develop critical thinking skills is a crucial factor in student academic performance [5].

Critical thinking is one of the essential skills in our daily lives to face the challenge of survival. On a day-to-day basis, people are faced with decisions that require reasoning, understanding, interpreting, analyzing and evaluating information. A process that involves critical thinking as it will enable one to make reliable and valid decisions, act ethically, and be able to adapt to changes in a particular environment [6]. According to Ennis (2011), critical thinking is to focus on logical thinking in making a decision what should be trusted and done the process of intellectual discipline [7]. Critical thinking skills are an intellectual process actively and skillfully conceptualize, apply, analyze, synthesize, evaluate information gathered and produced by observation, experience, reflection, reasoning, communication, as a guide to beliefs and actions $[8,9]$. Critical thinking is the primary thought process for analyzing arguments and generating insight into the meaning of particularity associated with directed thinking [10].

By learning science, students are expected training in solving a problem. Skills solving existing problems can be enhanced by training students' critical thinking skills [11]. Critical thinking skills are important to help one's selfpotential, developing talent, concentrating and focusing a problem [12].

According to Facione (2011) critical thinking consists of six aspects of indicators namely interpretation, analysis, evaluation, inference, explanation and self-regulation [9]. Developing students' critical thinking skills depends on the frequency of activities and exercises because each student has different critical thinking skills. Science lessons in schools show that theoretical still, learning strategies are still teacher-centered, learners during the learning process have not been actively involved so that less chance to construct their knowledge through experience and less developing the potential of empowering critical thinking skills. Based on this background, this study aims to analyze the profile of the critical thinking skills of students at Public Senior High School in Kediri.

\section{METHODS}

This research was conducted by using a descriptive qualitative method with a purposive sampling technique. Participants were all research sample of XI class students in a state senior high school in Kediri, amounting to 234 students. The test instrument was analyzed by using a quest program that obtained a mean test score of 15.20 , the standard deviation value of 5.17 with reliability internal consistency 0.79 . The test instrument in the form of an essay adapted to the critical thinking skill indicator according to Facione (2011) consists of interpretation aspects with subskills, i.e., categorization, codification significance, classifying meaning [9]. Aspects of analysis with sub-skill that is studying idea, detecting argument, argument analysis. Aspects of evaluation with sub skills assessing questions and 
assessing arguments. Aspects of inference with sub-skills are asking for proof, alternative allegations, concluding. Aspects of explanation with sub-skills that states the results, justify the procedure, presents arguments and aspects of selfregulation with sub-skills of self-examination, selfcorrection.

Each indicator of critical thinking skills is explored with one problem. The tests used in the analysis of critical thinking skills use the subject matter that students have already obtained. Item test based on the indicator of critical thinking skill according to Facione (2011) included interpretation, analysis aspect, evaluation aspect, inference aspect, explanation aspect and self-regulation aspect [9]. Data analysis conducted is qualitatively based on the data obtained. Data is organized, sorted, grouped and categorized according to Miles and Huberman Models, i.e., data reduction, display data, and conclusion drawing/verification.

Data in the form of a critical thinking skill test scores were analyzed using an assessment according to the assessment rating instrument provided rubric tool. The scores of test answers are given a score range of 1-4 for each item, and the total number of student scores for each question is summed then divided by the maximum total score (the number of students multiplied by the maximum score) and multiplied by one hundred percent. The score is analyzed per indicator or aspect with qualitative descriptive formula. Descriptive formula percentage is as follows.

\section{Amount of Score Achievement}

$$
\text { Scores per indicator }=\text { Maximum Score Total } \quad \text { x 100\% }
$$

The result of critical thinking skill analysis is then displayed in percentage form, then categorized based on criteria limitation. Criteria score category as follows.

Table....??

\begin{tabular}{cc}
\hline Percentage Scale & Category \\
\hline $86 \%-100 \%$ & Very good \\
$76 \%-85 \%$ & Good \\
$60 \%-75 \%$ & Enough \\
$55-59 \%$ & Less/Low \\
$54 \%$ & Very Less/Very Low \\
\hline
\end{tabular}

After analyzed with descriptive technique percentage then the data are described qualitatively and made conclusions.

\section{RESULTS AND DISCUSSION}

The results of the data obtained from the research are presented in Fig. 1. Fig.1 shows that students have the lowest critical thinking skills on self-regulation aspect of $38.20 \%$. The question presents the phenomena of life around. Of $61,80 \%$ of students in answering the description of the phenomenon is still less accurate and precise.

Contrarily, the presentation of the phenomenon is close to the daily life of the students. It is due to self-examination and self-correction of students is less.

According to Facione (2011) self-regulation of selfawareness monitors self-cognition, elements used in thought processes and developed outcomes, especially applying analytical skills, evaluating self-ability to conclude with questions, confirmation, validation, and correction [9]. Selfregulation is the ability of individuals to ensure that they are or have not been involved in critical thinking skills in monitoring personal cognitive activities [13]. Fundamental factors in capacity building, understanding focus, and selfregulated students will better understand [14-16]. Having a role helps students manage their thoughts, emotions, and behaviors to successfully guide, guide learning experiences in achieving goals [17].

The critical aspect of critical thinking receives the second lowest percentage is the inference of $40.16 \%$. The results are low due to lack of skills in asking alternative allegations to make conclusions that are still low and unfamiliar. The inference is a skill to identify and select the elements necessary to form a reasonable conclusion or to form a hypothesis concerning relevant information and to reduce the consequences of data, questions, principles, evidence, judgments, beliefs, opinions, concepts, descriptions, questions or any other form of representation. The conclusion aspect has three sub-skills: 1) asking for proof, 2) alternative guesswork and 3) concluding $[9,18]$. Students with inferred skills are more experienced or competent in the drawing, concluding, forming allegations or hypotheses according to reality, principles, evidence, judgments, beliefs, concepts, descriptions, questions, or other forms of representation [13]. The test results data show that there are still many students who have not been able to conclude the results correctly. 


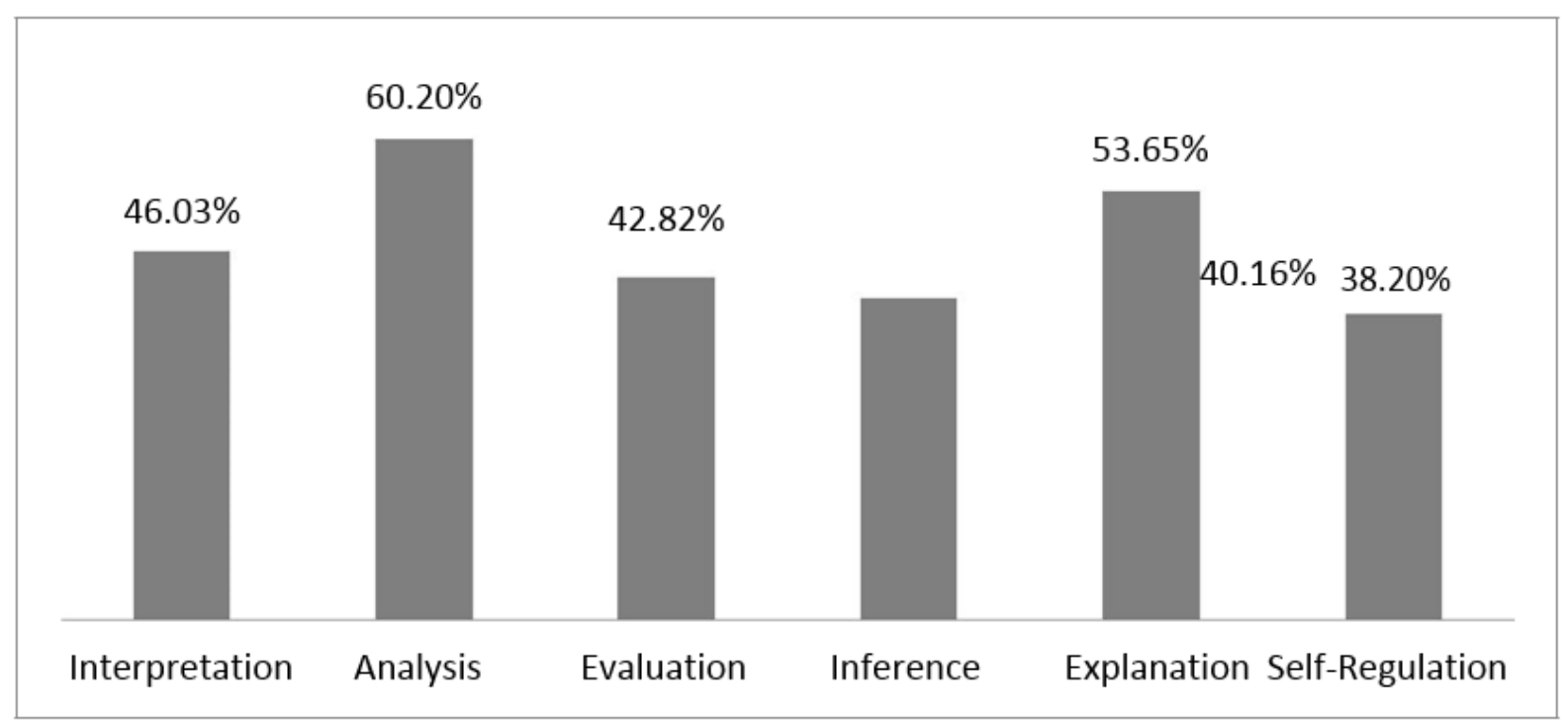

Fig. 1. Histogram result of percentage analysis of mean of factor aspect of student's critical thinking skill

The third lowest critical thinking aspect indicator is an evaluation of $42.82 \%$ with the low category. It is because students have difficulty and are less able to judge the credibility of statements and inquiries, causing the percentage of evaluation indicators to be low. Evaluation is a skill to assess the credibility of other questions or presentations by assessing or describing a person's perception, experiences, situations, decisions, beliefs, and assessing the logic power of normal inferential relationships or actual inferential relationships between statements, descriptions, questions or forms of representational representation other. The evaluation aspect has two subskills, i.e., assessing the question and assessing the argument [9]. Students with evaluation skills have more experience in assessing the validity of the questions, representations and assess the logical strength of statements or questions [13].

The fourth lowest critical thinking aspect indicator is a $46.03 \%$ interpretation with the low category. The results are low. This is possible because students are less able and have difficulty in categorizing, coding and classifying meaning. Interpretation is a skill in understanding, expressing the meaning of varied experiences, situations, data, events, decisions, conversions, beliefs, rules, procedural or criteria. Aspects of interpretation include three sub-skills among others; 1) categorization, 2) signification of coding and 3) clarifying meaning [9]. Students with interpretive skills are more competent in understanding, expressing the meaning of experiences, beliefs, rules, data during learning activities [13].

The fifth lowest critical thinking aspect indicator is an explanation of $53.65 \%$ with the low category. It is because students are less adept at declaring results, justifying procedures and presenting arguments. This result is consistent with studies suggesting that some cases of students lack clarity, criticality, and skill present an unfavorable argument $[19,20]$. The explanation is a skill to express the outcome of a person's balance process, the ability to justify that reason based on evidence, concepts, methodology, a specific criterion and reasonable judgment, and the ability to present a person's reason for a convincing argument. The critical aspect has three sub-skills consisting of; 1) states the results, 2) justifies the procedure and 3) presents the argument [9].

The highest score is the analysis reached $60.20 \%$. It is because students are less than optimal in reviewing ideas, detecting arguments and argument analysis. It is a skill to identify the true intentions of the conclusion in the relationship between questions, concepts, descriptions or forms of questions expected to express trust, decision, experience, reason, information or opinion. Aspects of analysis have three sub-skills namely; 1) studying ideas, 2) detecting arguments and 3) argument analysis [9,21]. Students who have competency analysis are more competent and able to identify inferential relationships, actual between statements, questions, concepts, and descriptions in expressing beliefs, judgments, experiences, reasons, and information [13].

Overall average score acquisition of critical thinking skills acquired $46.85 \%$ with the low category. Student indications are found at low levels of critical thinking skills [22]. Critical thinking skills of low students are affected by less activity, exercise, limited resources, the time-limiting environment in developing critical thinking skills [23]. Many students memorize, little thought and little mastery of the concept other than that basic knowledge is less so students cannot solve the problem [24]. It can be caused by other factors that affect [2]. The first factor, the level of quantity and quality of education among the countries of origin of the instrument of critical thinking skills aspects developed. United Stated developed countries and developing countries of Indonesia. The United States is a developed country with a high level of internationalization, educational standards, superior and excellent quality of education which is an important contextual factor that cannot be ignored compared to Indonesia as a developing 
country [25]. Based on an indication of the assessment of the 2015 International Program for Student Assessment (PISA), United Stated's critical thinking skill score reached 496 while Indonesia achieved only a score of 403 [26].

The second factor, the critical thinking skills used is a new type of matter for students so that students are less familiar with the types of questions. Type of matter problem that developed almost all pertained dimension aspects of critical thinking skills which included higher thinking skills. It is in line with the study which states that students' critical thinking skills have an uneven difference. There is still an outcome of the indicators of critical thinking skills with low achievement scores [4]. The third factor, many students who have little knowledge of science and experience, are less able to acquire and merely transfer content thinking skills. Students gain an understanding but fail to connect knowledge [27]. Therefore, knowledge science with learning strategies to stimulate and facilitate the students to dig, build skills critically understandable when students engage in active participation in learning and learning [28]. Actively involve students in the inquiry information, the application of knowledge, encourage students throughout the process and modeling the behavior of productive thinking and explicit in empowering critical thinking skills [24,29].

The result of the acquisition of the sixth score stale indicator of critical thinking skills difference between the difference in achievement scores lowest and the highest was $22 \%$. The gap between the ideal maximum score of $100 \%$ and a minimum of implementation less than $50 \%$ so need to be used as an evaluation of the process in organizing learning activities that can facilitate, develop and strengthen students' critical thinking skills. Curriculum 2013 that the current in all levels of educational units scrutinize students to master high-level skills [30]. Teachers can utilize the learning and teaching of integrated critical thinking skills [31]. In conformity with the objectives of the curriculum in 2013 that implement student-centered learning strategies using innovative learning models such as inquiry, projectbased learning, problem based learning, etc. The expectation increases critical thinking skills students obtain optimal alignment results well in every aspect of critical thinking skills indicators [4]. Teachers must have a clear foothold orientation in designing and organizes education as develop, construct and design a specific subject pedagogy with models of innovative learning to achieve the requirements in developing, empowering critical thinking skills of students as well as an essential step toward improving the overall education [32-34]

\section{CONCLUSION}

Based on the results of data analysis can be concluded that the critical thinking skills of XI grade student of the State Senior High School are still categorized as low. Students have a low level of understanding of critical thinking skills. Teachers are expected to develop and design the Specific Subject Pedagogy (SSP) with innovative learning models that can empower students' critical thinking skills.

\section{ACKNOWLEDGMENT}

Researchers would like to thank all those who have helped in this research especially teachers and students of Public Senior High School in Kediri.

\section{REFERENCES}

[1] Wilson, K., "Critical reading, critical thinking: Delicate scaffolding in English for Academic Purposes (EAP)," Thinking Skills and Creativity, vol. 22, pp. 256-265, 2016.

[2] Mahapoonyanont, N., "The Causal Model of Some Factors Affecting Critical Thinking Abilities. Procedia - Social and Behavioral Sciences," vol. 46, pp. 146-150, 2012.

[3] Carmichael, E., \& Farrell, H., "Evaluation of the Effectiveness of Online Resources in Developing Student Critical Thinking: Review of Literature and Case Study of a Critical Thinking Online Site," Journal of University Teaching \& Learning Practice, vol. 9(91), pp. 1-17, 2012.

[4] Qing, Z., Ni, S., and Hong, T., "Developing critical thinking disposition by task-based learning in chemistry experiment teaching", Procedia Social and Behavioral Sciences, vol. 2(2), pp. 4561-4570, 2010.

[5] Taghva, F., Rezaei, N., Ghaderi, J., and Taghva, R., "Studying the Relationship between Critical Thinking Skills and Students' Educational Achievement ( Eghlid Universities as Case Study)," International Letters of Social and Humanistic Sciences, vol. 25, pp. $18-25,2014$

[6] Chukwuyenum, A. N., "Impact of Critical thinking on Performance in Mathematics among Senior Secondary School Students in Lagos State," Journal of Research \& Method in Education, vol. 3.5(5), pp. $18-25,2013$.

[7] Ennis, R. H., "The Nature of Critical Thinking: An Outline of Critical Thinking Dispositions," University of Illinois, 2011, pp. 1-8.

[8] Scriven, M., \& Paul, R. “ defining Critical Thinking. Community Foundation for Critical Thinking. Retrieved January 2. University Library, 2007.

[9] Facione, P. A, Critical Thinking: What It Is and Why It Counts, 2011.

[10] Arthur, L., and Costa, A. L., Developing mind: A Resource Book for Teaching Thinking. Revised Edition, Volume 1, 1985.

[11] Hazeli, S. \& Rezaii, F., "The Effect of Teaching Critical Thinking on Educational Achievement and Test Anxiety among Junior High School Students in Saveh. Department of Psychology, save Brach, Islamic Azad University, Saveh, Iran," European Online Journal of Natural and Social Sciences, vol. 2(2), 2013.

[12] Tung, C.A ., Hou Chang \& Sung Yung., "Developing Critical Thinking Though Literature Reading. Feng Chia Journal of Humanitie an Social Science, vol. 19, pp. 287-317, 2009.

[13] Ricketts, J. C., and Rudd, R., "Critical Thinking Skills of FFA Leaders John C. Ricketts, University of Georgia Rick Rudd, University of Florida," Agricultural Education, vol. 54(1), pp. 7-20, 2004.

[14] Jafarigohar, M., "The Effect of Self-Regulation on Improving EFL Readers 'Ability to Make Within - Text Inferences," Issues in Language Teaching, vol. 3(2), pp. 263-286, 2014.

[15] Abbasian, G.-R., and Hartoonian, A., "Using self-regulated learning strategies in enhancing language proficiency with a focus on reading comprehension" English Language Teaching, vol. 7(6), pp. 160-167, 2014.

[16] Kamgar, N., and Jadidi, E., "Exploring the Relationship of Iranian EFL Learners â€TM Critical Thinking and Self-regulation with their Reading Comprehension Ability," Procedia - Social and Behavioral Sciences, vol. 232(April), pp. 776-783, 2016.

[17] Zumbrunn, S., Tadlock, J., and Roberts, E. D., "Encouraging SelfRegulated Learning in the Classroom: A Review of the Literature", 2011.

[18] Facione, P. A., and Carlin, G. 2007 Update Critical Thinking: What It Is and Why It Counts, 2007.

[19] Engege, S., and Kulieleh, S., "Critical Thinking: Teaching Foreign Nations to Foreign Students, Internasional Education Journal, vol. 4 (4), pp. 75-85, 2004. 
[20] Fell, E. V, and Lukianova, N. A., "British universities: international students' alleged lack of critical thinking," Procedia -Social and Behavioral Sciences, vol. 215, pp. 2-8, 2015.

[21] Peter, A., \& Price, E. (1990). Using the California Critical Thinking Skills Test.

[22] Smetanová, V., Drbalová, A., and Vitáková, D., "Implicit Theories of Critical Thinking in Teachers and Future Teachers," Procedia - Social and Behavioral Sciences, vol. 171, pp. 724-732, 2015.

[23] Snyder, L. G., and Snyder, M. J., "Teaching Critical Thinking and Problem-Solving Skills How Critical Thinking Relates to Instructional Design", pp. 90-100, 2008.

[24] Peter, E. E., "Critical thinking : Essence for teaching mathematics and mathematics problem-solving skills", vol. 5(3), pp. 39-43, 2012.

[25] Dobrescu, P., and Radu, L., "A Qualitative Inquiry Into the Europeanization of Romanian Higher-education," Procedia - Social and Behavioral Sciences, vol. 228, pp. 476-481, 2016.

[26] Marôco, J., and Gonçalves, C., "Pisa 2015," vol. 16, 2015.

[27] Beyer, B. K., "What Research Tells Us about Teaching Thinking Skills," The Social Studies, vol. 99(5), pp. 223-232, 2008.

[28] Tiruneh, D. T., Verburgh, A., and Elen, J., "Effectiveness of Critical Thinking Instruction in Higher Education: A Systematic Review of Intervention Studies," vol. 4(1), 2014.

[29] Zivkovic, S., “ A Model of Critical Thinking as an Important Attribute for Success in the $21^{\text {st }}$ Century “, Procedia- Social and Behavioral Sciences, vol. 232, pp. 102-108, 2016.

[30] Litbang Kemendikbud, “ The Documen of Curriculum 2013”. Jakarta : Kemendikbud, 2013.

[31] Aizikovitsh-Udi, E., and Amit, M., "Developing the skills of critical and creative thinking by probability teaching," Procedia - Social and Behavioral Sciences, vol. 15, pp. 1087-1091, 2011.

[32] McDiarmid, G.W. Ball Loewenberg. D and Anderson. C.H., "Why Staying One Chapter Ahead Doesn't Really Work: Subject Specific Pedagogy,"National Center for Research on Teacher Education, Erickson Hall, 1989.

[33] Janjai, S., "Improvement of the Ability of the Students in an Education Program to Design the Lesson Plans by Using an Instruction Model based on the Theories of Constructivism and Metacognition," Procedia Engineering, vol. 32, pp. 1163-1168, 2012.

[34] Maričića, S., and Špijunovićb, K., "Developing Critical Thinking in Elementary Mathematics Education through a Suitable Selection of Content and Overall Student Performance," Procedia - Social and Behavioral Sciences, vol. 180, pp. 653-659, 2015. 